\title{
Measuring Cost of Children Using Equivalence Scale on Japanese Panel Data
}

\author{
Masako Oyama ${ }^{1}$ \\ Faculty of Economics, Hitotsubashi University
}

\begin{abstract}
In this paper, the cost of child rearing is estimated in order to examine the hypothesis that the recent fertility decline in Japan has been caused by increases in the cost of child rearing. Although there are various ways to estimate the cost of children, the research uses an equivalence scale. The results of the traditional Rothbarth estimation showed that the cost of child raising in Japan is not very high. However, the results of the equivalence scale estimation using "satisfaction for the income" as the utility measure showed that the cost of child raising is much higher than calculated in the Rothbarth model. The latter subjective scale approach is now said to have more advantages. Thus, the cost of child raising in Japan is much higher than was believed to be the case, and this could be one of the reasons for the decline in the fertility rate in Japan.
\end{abstract}

\footnotetext{
${ }^{1}$ 3-5-16-301, Honcho, Kokubunji, Tokyo 185-0012 JAPAN. Tel/Fax +81-42-324-7855

For their helpful advice, I thank Noriyuki Takayama, Yukinobu Kitamura, Cheng Hsiao, Naohito Abe, Tokuo Iwaisako, Nobuko Nagase, Terukazu Suruga, Hiroshi Yoshida, Hiroshi Ogawa, and participants of the seminar of the Project of Intergenerational Equity at Hitotsubashi University, 2003 Fall Conference of the Japan Economic Association, Macro-lunch seminar at Hitotsubashi University, seminars at the University of Tsukuba, the Institute for the Research on Household Economics, and the Labor Market Research Committee. The paper is part of the academic Project on Intergenerational Equity (PIE), funded by a scientific grant from Japan's Ministry of Education, Culture, Sports, Science and Technology (grant number 603). Also, this research is funded by a scientific grant B for young researchers from Japan’s Ministry of Education, Culture, Sports, Science and Technology. Email : oyama@econ.hit-u.ac.jp
} 


\section{Introduction}

My paper examines why, in Japan, the total fertility rate (TFR) has been in decline since 1973, reaching the low level of 1.29 in 2003, which is far below the replacement rate of 2.08. Also recently, the delay of childbearing among young married couples is said to account for more than half of this decline (Suzuki 2000). The high cost of child rearing, resulting from greater expenditure on children and parental funding of their children's higher education, is said to be one of the causes of this delay. Therefore, in this research, the cost of child raising is estimated using an equivalence scale to analyze whether child rearing costs are very high in Japan or not.

There are many research publications on the equivalence scale. Deaton and Muellbauer (1986) suggested measuring this cost using the Engel or Rothbarth models of the equivalence scale. Tsakloglou (1991), Melenberg and Soest (1996), Charlier (2002), Mutoh (1992), Suruga (1993, 1995), Nagase (2001) and Suruga and Nishimoto (2001) undertook such estimations using Japanese data. Recently, Perali (2002) showed the legitimacy of the Engel model of the equivalence scale, and Van Praag and Warnaar (2003) carried out an extensive survey. The contribution of this paper is that an income satisfaction measure is estimated for the first time with Japanese data. In addition, Japanese panel data is used extensively for the first time to estimate Equivalence Scale.

\section{Equivalence Scale}

Following Van Praag and Warnaar (2003), I consider a household utility of $u=u(q, z)$ under a budget constraint $p^{\prime} q=y_{i} . q$ is the commodity vector $q \in R^{n}, p$ is the price vector $p \in R^{n}$, while $y$ is the household income, and $z$ is the household composition. I define $C(u, p, z)$ as the household cost function to attain the utility level $u$, given the price $p$. Moreover, I assume that households of the same composition have an identical preference, which in turn leads to an identical household cost function. If $z_{0}$ denotes a reference household type, then,

$$
E(c, p, z)=c(u, p, z) / c\left(u, p, z_{0}\right)
$$

is the equivalence scale with respect to the reference household $z_{0}$.

There are several different ways to measure the cost of children with an equivalence scale, such as the Engel and the Rothbarth models. The complete demand system approach and subjective scale approach are very different from the Engel and Rothbarth models. Here, two of these methods are used. The first is the Rothbarth model and the second is the use of an income satisfaction measure (subjective scale approach).

According to the Rothbarth model, the goods and services consumed by a household can be divided into two groups: those consumed exclusively by adults ("adult goods"), and those that are usually consumed jointly by adults and children ("other goods"). It is assumed that the level of a couple's welfare is determined solely by their consumption of adult goods. In this way, the Rothbarth model assumes a very specific utility function.

On the other hand, in the second method, how a couple feels about their income, that is, their relative satisfaction level with their income, is used to represent the couple's welfare level. In this model, a general utility function is allowed, since the welfare level of adults is directly measured. 


\section{Data}

The data used in this research are Japanese Panel Survey on Consumers (JPSC) from the Household Survey by the Institute for the Research on Household Economics. The data consist of observations for the seven years between 1993 and 1999. The survey started with 1,500 women aged between 24 and 34 (cohort A), and 500 women aged between 24 and 27 were added from 1997 (cohort B). Among these observations, only the data on married women are used in the research because out-of-wedlock births are still rare in Japan. The variable definition is shown in Table 1 and the summary statistics of the pooled data are shown in Table 2.

For the estimation of the Rothbarth model, we need the data on the expenditure on "the adult goods", such as alcohol or adult clothing. Although the Household Survey does not have the data on expenditures on all consumer goods, it does have the data on the monthly expenditures for the whole household, including husband, wife, children, and other family members. Following Suruga and Nishimoto (2001), I treat the "expenditure for wife" and "expenditure for husband" as the expenditure for adult goods, and the sum of the two expenditures is combined into one variable: ExpenHusWi.

For the estimation using "satisfaction with income", I used the variable IncomeSatisf, which takes the discrete values from 1 to 4 , where 4 means the highest satisfaction with current income. This variable is constructed from the question, "are you satisfied with your current income?"; 4 means "very satisfied”, 3 "mostly satisfied”, 2 "relatively unsatisfied", and 1 denotes "very unsatisfied". This variable can be obtained only from the third year (1995) until the last year (1999).

\section{Estimation Results}

Firstly, the estimated equation for the Rothbarth model is:

$$
\text { ExpenHusWi }=\alpha_{0}+\alpha_{1} \text { LnExpTotal }+\sum_{j} \alpha_{j} n_{j}+\sum_{k} \alpha_{k} \text { YearDummy }_{k}+u_{1}
$$

where LnExpTotal is the logarithm of the monthly total expenditure for the household, and $n_{j}$ is the number of children in each age category. Then, the equivalence scale for one child in age category $\mathrm{j}$ can be easily calculated as $\exp \left(-\alpha_{j} / \alpha_{i}\right)$ (Deaton and Muellbauer 1986). This equivalence scale is equal to the total expenditure for the comparison household to reach the same consumption level of "adult goods" as the reference household, divided by the total expenditure of the reference household.

The estimation results for the Rothbarth model are shown in Table 3. The random effects model is shown to give us the efficient and consistent estimator, as the results of the Hausman test and Breusch-Pagan tests. All of the random effect coefficient estimates are statistically significant to a $1 \%$ level, and the cost of children from the calculated equivalence scale for child age ranges is 1.13 for a child aged $0-18,1.124$ for a child aged $0-6,1.26$ for a child aged $7-13$, and 1.26 for a child aged $14-18$. These figures mean that $12.4 \%$ of the expenditure of married couples is needed to raise a child aged 0 to 18 years. These estimates are consistent with other Japanese research (e.g., Mutoh 1992; Suruga 1993, 1995; Nagase 2001).

If we review the Rothbarth estimates from other countries, Deaton and Muellbauer (1986) obtained 1.12 with data from Sri Lanka between 1969 and 1970, and Deaton, RuizCastill and Thomas (1989) showed 1.22 for a child aged 5 to 8 using data from Spain between 1980 and 1981. In addition, Tsakloglou (1991) had estimates of 1.091 for a child aged 0 to 5 and 1.130 for child aged 6 to 13 with data from Greece during 1980 and 1981. Japanese results are similar to these estimates. 
Secondly, the estimation result with satisfaction with income is shown in Table 4. This type of estimation with an income satisfaction measure has recently become popular since it allows us to directly measure the utility level without using some very specific utility function (Van Praag and Warnaar 2003). The estimated equation is:

$$
\text { IncomeSatisf }=\alpha_{0}+\alpha_{1} \text { LnExpTotal }+\sum_{j} \alpha_{j} n_{j}+\sum_{k} \alpha_{k} \text { YearDummy }_{k}+u_{2} \text {. }
$$

The estimates with OLS, ordered probit, random effect ordered probit, and fixed effect are shown in Table $4 .^{2}$ The estimates obtained here exhibit much higher figures than those from the Rothbarth model. The Rothbarth model used the utility function of the parents, which depends solely on their consumption of adult goods. Using the direct income satisfaction measure as the utility enables researchers to avoid using this extreme utility function. Thus, as this estimation method is more desirable it has been used more frequently in recent research (e.g., Melenberg and Soest 1996; Charlier, 2002). According to Table 4 the cost of a child aged $0-18$ years is between 1.386 and 1.475. For each age group, it is between 1.280 and 1.454 for a child aged $0-6,1.277$ to 1.407 for the age range $7-13$ years and 2.090 to 4.329 for the age range $14-18$. The high cost of a child aged 14 to 18 years may reflect the high cost of education. This estimation, using income satisfaction and Japanese data, is utilized for the first time in this paper, and the estimation results are much higher than the existing estimate results of the Rothbarth or Engel models. ${ }^{3}$ Therefore, these estimates imply that the cost of child rearing in Japan has been higher than the level shown in previous literature. Therefore, the question arises, do Japanese couples choose to have fewer children, but spend more on each of them?

\section{Conclusion and Further Research}

In this paper, the cost of children is estimated in two ways, based on equivalence scales using panel data from Japan. Although the traditional Rothbarth model showed that the cost of children is not high, the estimation results of the new subjective scale approach showed that the cost of children is significantly higher in Japan. Therefore, this high cost may be one of the causes of low fertility. The empirical investigation of the influence of these high costs on the fertility rate will be the focus of future research.

\footnotetext{
${ }^{2}$ The data on the satisfaction with income are available only from the third year of the survey. Therefore, this estimation was made with 5-year panel data.

${ }^{3}$ In evaluating this result, we need to pay attention to the fact that the Rothbarth model tends to underestimate the cost while the Engel model tends to overestimate the cost. However, the income satisfaction measure shows a higher cost than either the Japanese Rothbarth or Engel model estimates.
} 
Table1 Definition of the variables

\begin{tabular}{ll}
\hline Variable & Definitions \\
\hline id_no & ID number of the observation \\
kaisuu & Panel number $1 \sim 7$ \\
ExpenTotal & Monthly Total expenditure of the household \\
ExpenHusWi & Monthly Total expenditure for husband and wife \\
LnExpTotal & Log of Monthly Total expenditure of the household \\
LnExpHusWi & Log of Monthly Total expenditure for husband and wif \\
IncomeSatisf & Satisfaction with Income \\
Child 0-6 & number of children aged 0 to 6 \\
Child 7-13 & number of children aged 7 to 13 \\
Child 14-18 & number of children aged 14 to 18 \\
Child 0-18 & number of children aged 0 to 18 \\
Year94 & Dummy=1 if year is 1994 \\
Year95 & Dummy=1 if year is 1995 \\
Year96 & Dummy=1 if year is 1996 \\
Year97 & Dummy=1 if year is 1997 \\
Year98 & Dummy=1 if year is 1998 \\
Year99 & Dummy=1 if year is 1999 \\
\hline
\end{tabular}


Table2 Summary Statistics of the Pooled Data

\begin{tabular}{|c|c|c|c|c|c|}
\hline Variable & \# of obs & Mean & Std.Dev. & Min & $\operatorname{Max}$ \\
\hline id_no & 7498 & - & - & 1 & 2499 \\
\hline kaisuu & 7498 & - & - & 1 & 7 \\
\hline ExpenTotal & 7278 & 213.348 & 98.255 & 13 & 998 \\
\hline ExpenHusWi & 7231 & 45.545 & 41.899 & 0 & 715 \\
\hline LnExpTotal & 7278 & 5.264 & 0.457 & 2.565 & 6.906 \\
\hline LnExpHusWi & 6168 & 3.763 & 0.682 & 0 & 6.572 \\
\hline IncomeSatisf & 5470 & 2.399 & 0.706 & 1 & 4 \\
\hline Child 0-6 & 7498 & 1.016 & 0.868 & 0 & 4 \\
\hline Child 7-13 & 7498 & 0.610 & 0.827 & 0 & 4 \\
\hline Child $14-18$ & 7498 & 0.064 & 0.292 & 0 & 3 \\
\hline Child 0-18 & 7498 & 1.691 & 0.964 & 0 & 5 \\
\hline Year94 & 7498 & 0.136 & - & 0 & 1 \\
\hline Year95 & 7498 & 0.133 & - & 0 & 1 \\
\hline Year96 & 7498 & 0.132 & - & 0 & 1 \\
\hline Year97 & 7498 & 0.157 & - & 0 & 1 \\
\hline Year98 & 7498 & 0.153 & - & 0 & 1 \\
\hline Year99 & 7498 & 0.152 & - & 0 & 1 \\
\hline \multicolumn{6}{|c|}{ *Number of observations for each year in the Panel } \\
\hline & $1 \quad 1002$ & & $5 a$ & 980 & \\
\hline & 1005 & & $5 b$ & 201 & \\
\hline & 1000 & & 6 & 1163 & \\
\hline & 1001 & & 7 & 1146 & \\
\hline
\end{tabular}


Table3 Dependent variable : ExpenHusWi (Exp. for husband and wife)

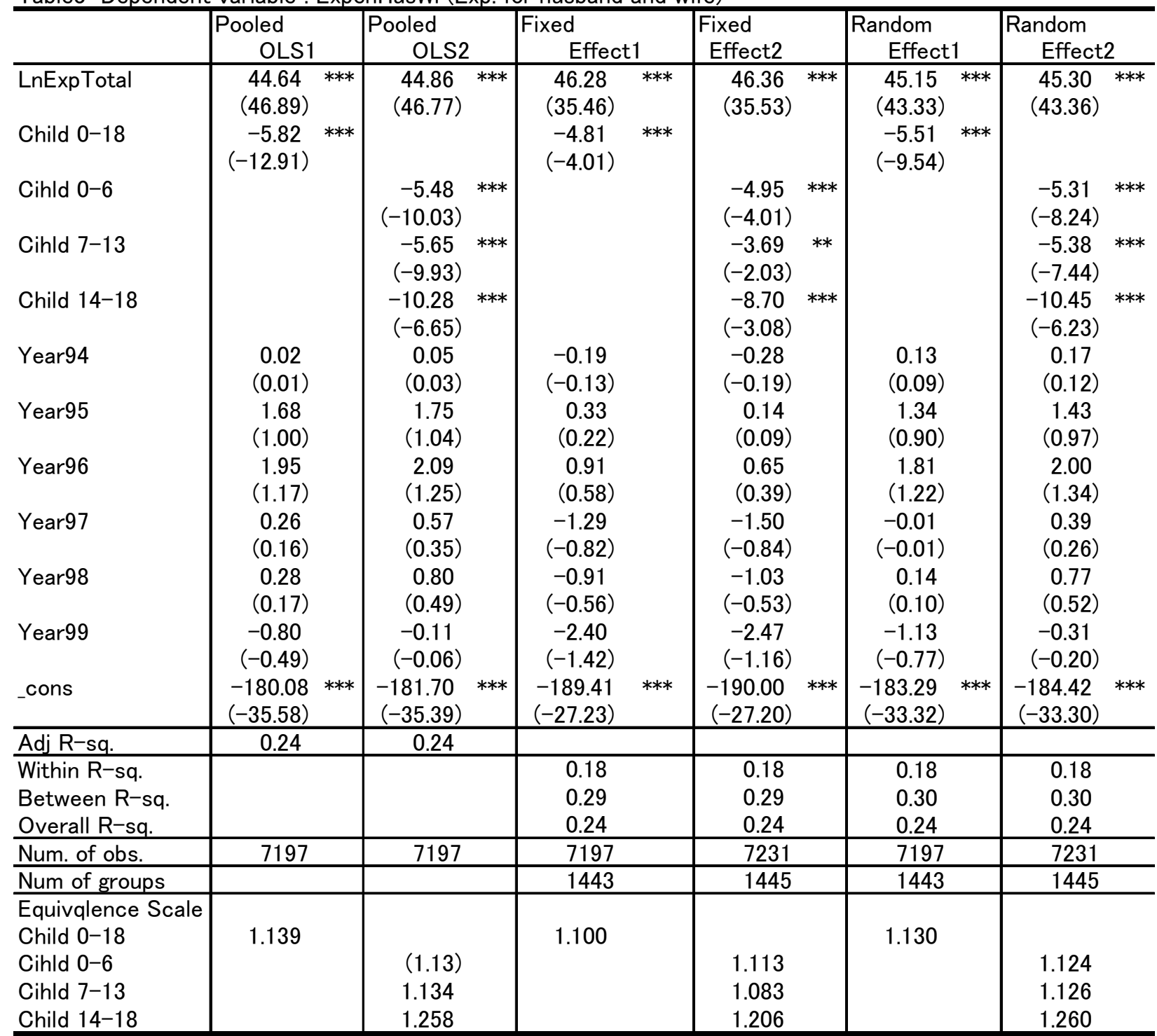

***:significant at $1 \%$ level, $* *$ : significant at $5 \%$ level

$*$ : significant at $10 \%$ level

( $t$-value in parenthesis for OLS, $z$-value for FE and RE)
Hausman test: FE vs RE

HO: Differences in coefficients not systematic $\operatorname{chi} 2(10)=6.15 \quad \operatorname{chi} 2(12)=9.49$

$\rightarrow \mathrm{HO}$ Not reject, $\mathrm{RE}$

Breusch-Pagan test (LM test) : Pooled OLS vs RE $\mathrm{H} 0: \operatorname{Var}(\mathrm{u})=\mathrm{o}$

$$
\begin{aligned}
\operatorname{chi} 2(1)=987 & \text { chi } 2(1)=988 \\
& \rightarrow \mathrm{H} 0 \text { reject, } \mathrm{RE}
\end{aligned}
$$


Table4 Dependent variable: Satisfaction with Income

\begin{tabular}{|c|c|c|c|c|c|c|c|c|}
\hline & $\begin{array}{l}\text { Pooled } \\
\text { OLS } 1\end{array}$ & $\begin{array}{l}\text { Pooled } \\
\text { OLS } 2\end{array}$ & $\begin{array}{l}\text { Ordered } \\
\text { Probit } 1\end{array}$ & $\begin{array}{l}\text { Ordered } \\
\text { Probit } 2\end{array}$ & \begin{tabular}{|l|} 
Random Effect \\
Ordered Probit 1
\end{tabular} & $\begin{array}{l}\text { Random Effect } \\
\text { Ordered Probit } 2\end{array}$ & $\begin{array}{l}\text { Fixed } \\
\text { Effect } 1\end{array}$ & $\begin{array}{l}\text { Fixed } \\
\text { Effect } 2\end{array}$ \\
\hline LnExpTo & $\begin{array}{l}0.21 \text { *** } \\
(9.98)\end{array}$ & $\begin{array}{l}0.22 \\
(10.26)\end{array}$ *** & $\begin{array}{l}0.33 \text { *** } \\
(9.94)\end{array}$ & $\begin{array}{l}0.34 \text { *** } \\
(10.22)\end{array}$ & $\begin{array}{c}0.35 \quad * * * \\
(6.28)\end{array}$ & $\begin{array}{c}0.35 \quad * * * \\
(6.31)\end{array}$ & $\begin{array}{l}0.08 \text { *** } \\
(3.37)\end{array}$ & $\begin{array}{l}0.08 \text { *** } \\
(3.47)\end{array}$ \\
\hline Child018 & $\begin{array}{l}0.07 \text { *** } \\
(-6.91)\end{array}$ & 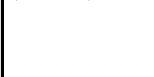 & $\begin{array}{l}-0.11 \text { *** } \\
(-6.87)\end{array}$ & 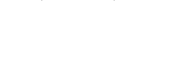 & $\begin{array}{l}-0.14 \text { *** } \\
(-3.63)\end{array}$ & & $\begin{array}{c}-0.03 \\
(-1.20)\end{array}$ & \\
\hline Child06 & & $\begin{array}{l}-0.05 \quad * * * \\
(-4.46)\end{array}$ & & $\begin{array}{l}-0.09 * * * \\
(-4.41)\end{array}$ & & $\begin{array}{l}-0.13 * * * \\
(-3.28)\end{array}$ & & $\begin{array}{c}-0.03 \\
(-1.10)\end{array}$ \\
\hline Child713 & & $\begin{array}{l}-0.07 \text { *** } \\
(-5.49)\end{array}$ & & $\begin{array}{l}-0.11 \text { *** } \\
(-5.52)\end{array}$ & & $\begin{array}{l}-0.12 \text { *** } \\
(-2.65)\end{array}$ & & $\begin{array}{l}-0.03 \\
(-0.71)\end{array}$ \\
\hline Child1418 & & $\begin{array}{l}-0.16 \text { *** } \\
(-5.44)\end{array}$ & & $\begin{array}{l}-0.25 * * * \\
(-5.37)\end{array}$ & & $\begin{array}{l}-0.35 * * * \\
(-4.05)\end{array}$ & & $\begin{array}{l}-0.12 \text { *** } \\
(-2.89)\end{array}$ \\
\hline Year96 & $\begin{array}{c}0.02 \\
(-0.50)\end{array}$ & $\begin{array}{l}-0.01 \\
(-0.44)\end{array}$ & $\begin{array}{l}-0.03 \\
(-0.55)\end{array}$ & $\begin{array}{l}-0.02 \\
(-0.48)\end{array}$ & $\begin{array}{l}-0.03 \\
(-0.52)\end{array}$ & $\begin{array}{l}-0.03 \\
(-0.46)\end{array}$ & $\begin{array}{c}-0.01 \\
(-0.65)\end{array}$ & $\begin{array}{c}-0.02 \\
(-0.89)\end{array}$ \\
\hline Year97 & $\begin{array}{c}0.00 \\
(0.06)\end{array}$ & $\begin{array}{c}0.01 \\
(0.27)\end{array}$ & $\begin{array}{c}0.01 \\
(0.13)\end{array}$ & $\begin{array}{c}0.02 \\
(0.33)\end{array}$ & $\begin{array}{c}0.00 \\
(-0.03)\end{array}$ & $\begin{array}{c}0.01 \\
(0.18)\end{array}$ & $\begin{array}{l}-0.01 \\
(-0.48)\end{array}$ & $\begin{array}{l}-0.02 \\
(-0.85)\end{array}$ \\
\hline Year98 & $\begin{array}{r}0.05 \\
(-1.49)\end{array}$ & $\begin{array}{c}-0.03 \\
(-1.12)\end{array}$ & $\begin{array}{c}-0.07 \\
(-1.47)\end{array}$ & $\begin{array}{c}-0.05 \\
(-1.11)\end{array}$ & $\begin{array}{l}-0.14 \text { ** } \\
(-2.32)\end{array}$ & $\begin{array}{l}-0.11 \\
(-1.89)\end{array} *$ & $\begin{array}{l}-0.06 \quad * * * \\
(-2.86)\end{array}$ & $\begin{array}{l}-0.08 \text { *** } \\
(-2.97)\end{array}$ \\
\hline Year99 & $\begin{array}{c}0.04 \\
(-1.17)\end{array}$ & $\begin{array}{l}-0.02 \\
(-0.66)\end{array}$ & $\begin{array}{c}-0.06 \\
(-1.13)\end{array}$ & $\begin{array}{c}-0.03 \\
(-0.63)\end{array}$ & $\begin{array}{l}-0.11 * \\
(-1.91)\end{array}$ & $\begin{array}{c}-0.08 \\
(-1.35)\end{array}$ & $\begin{array}{l}-0.06 \quad * * * \\
(-2.59)\end{array}$ & $\begin{array}{l}-0.08 \text { *** } \\
(-2.67)\end{array}$ \\
\hline _cons & $\begin{array}{l}0.43 \quad * * * \\
(3.84) \\
\end{array}$ & $\begin{array}{l}2.09 \text { *** } \\
(3.31) \\
\end{array}$ & & & & & $\begin{array}{r}2.04 \\
(16.25)\end{array}$ & $\begin{array}{l}2.02 \text { *** } \\
(16.15)\end{array}$ \\
\hline Adj R-sq. & 0.02 & 0.02 & & & & & & \\
\hline Num. of obs & 5335 & 5183 & 5335 & 5335 & 5335 & 5335 & 5335 & 5335 \\
\hline Num. of groups & & & & & & & 1358 & 1358 \\
\hline $\begin{array}{l}\text { eqivalence scale } \\
\text { Child } 0-18 \\
\text { Child } 0-6 \\
\text { Child } 6-13 \\
\text { Child } 14-18\end{array}$ & 1.388 & $\begin{array}{l}1.284 \\
1.366 \\
2.113 \\
\end{array}$ & 1.386 & $\begin{array}{l}1.280 \\
1.368 \\
2.090\end{array}$ & 1.475 & $\begin{array}{l}1.454 \\
1.407 \\
2.737\end{array}$ & 1.427 & $\begin{array}{l}1.375 \\
1.277 \\
4.329\end{array}$ \\
\hline
\end{tabular}

( $t$-value in parenthesis for OLS and FE, $z$-value for Ordered Probit and RE Ordered Probit) 


\section{References}

Charlier, E. (2002) "Equivalence Scales in an Inter-temporal Setting with an Application to the Former West Germany” Review of Income and Wealth 48, 99-126.

Deaton, A.A., and J. Muellbauer (1986) "On Measuring Child Cost: With Applications to Poor Countries” Journal of Political Economy 94, 720-744.

Deaton, A.A., J. Ruiz-Castillo and D. Thomas (1989) "The Influence of Household Composition on Household Expenditure Patterns: Theory and Spanish Evidence” Journal of Political Economy 97, 179-200.

Melenberg, B., and A.H.O. Soest (1996) "Measuring the Costs of Children: Parametric and Semiparametric Estimators” Statistica Neerlandica 50(1), 171-192.

Nagase, N. (2001) "Estimation of Cost of Children: Using Japanese Household Expenditure and Asset Data” (in Japanese) Jinko-gaku kenkyu 28, 1-15.

Perali, F. (2002) "Some curiosities about the Engel method to estimate equivalence scales" Economics Bulletin 4(9), 1-7.

Suruga, T. (1993) “Estimation of Equivalence Scales Using Japanese Data,” Economic Studies Quarterly 44, 169-177.

Suruga, T. (1995) "Measurement of Equivalence Scales for Children” (in Japanese) Japanese Journal of Statistics (Nihon Tokei Gakkai Zasshi) 25(3), 223-231.

Suruga, T., and M. Nishimoto (2001) "Equivalence Scale and Cost of Children - Using the Household Panel Data” (in Japanese) Japanese Journal of Research on Household Economics (Kikan Kakei Keizai Kenkyu) 50, 25-31.

Suzuki, T. (2000) “On the Recent Decline of Marriage and Fertility Rate” (in Japanese) Japanese Journal of Research on Household Economics (Kikan Kakei Keizai Kenkyu) 47, 1319.

Tsakloglou, P. (1991) "Estimation and Comparison of Two Simple Models of Equivalence Scales for the Cost of Children,” Economic Journal, 101, 343-357.

Van Praag, B.M.S., and M.F. Warnaar (2003) "The Cost of Children and the Use of Demographic Variables in Consumer Demand” in Handbook of Population and Family Economics Vol.1A by Mark R.Rosenzweg and Oded Stark, North-Holland, 241-273. 